UDC 811

DOI https://doi.org/10.32838/2663-6069/2020.3-1/26

Mykhaylenko $\boldsymbol{V}$. $\boldsymbol{V}$.

King Danylo University

\title{
PROFORMS REVISITED
}

The present paper is focused at specific units which belong to different word classes, but sharing a common component they can model a conceptual subsystem in the English language worldview.

The transition from prescriptive to descriptive grammar found a student in dificulty to determine a part of speech class of many a word in the text despite a clear-cut classification of words into closed (prepositions, pronouns, conjunctions, articles or determiners) and open (nouns, adjectives, numerals, verbs and adverbs). No doubt, the given classification is contraversial as for the number of classes and their nominations, however, it can serve as a starting point for the morphological analysis of words in discourse wherin the meaning of the word in its context is a primary marker. Though I would suggest to begin the text/discourse study with the conceptual analysis gradually approaching the morphemic representation of the concept.

Proforms can be organized into a paradigm of substition units in written and oral discourse though this paradigm is not homogeneous as it differentiates between: 1) the "relative substitutes" (structural elements like it (a formal subject), that (a complementizer or a conjunction), etc.) and 2) "direct substitutes" (like personal and demonstrative pronouns, modal and auxiliary verbs, etc.), and semantically bleached words like one or thing, etc.

It is argued that these proforms do not necessarily express a unit at any level of underlying representation. Instead an alternative account of the use of proforms is suggested, emplying the theory of Functional Discourse Grammar, which, with its four different levels of analysis (representing pragmatic, semantic, morphosyntactic and phonological information), possesses the kind of flexibility needed to deal with English proforms in a consistent and unified manner. It is proved that without using pro-forms in language, it is almost impossible to produce natural, cohesive texts, either written or spoken M. A. K. Halliday and R. Hasan (1975) systematized the major cohesive resources in their book on cohesion.

Key words: part of speech, substitute, polifunctional, sentence, discourse, contextual semantics, concept.

Introduction. The transition from prescriptive to descriptive grammar found a student in dificulty to determine a part of speech class of many a word in the text despite a clear-cut classification of words into closed (prepositions, pronouns, conjunctions, articles or determiner) and open (nouns, adjectives, numerals, verbs, and adverbs). No doubt, the given classification is contraversial as for the number of classes and their nominations, however, it can serve as a starting point for the morphological analysis of words in discourse wherin the meaning of the word in its context is a primary marker. Though I would suggest to begin the text/discourse study with the conceptual analysis gradually approaching the morphemic representation of the concept [11, p. 77]. We have retrieved the most frequent, polysemous, and multifunctional units personal pronoun the $3^{\text {rd }}$ person, that. one, and do from the British National Corpus which share the dominant component "substitution". These units are referred by R. Quirk et al. to proforms (pro-forms) [14, p. 865-866], words or combination of words which stand in for a more specific word or expression in the phrase, sentence, text/discourse. We understand that form, function and meaning have been the basic principles of the word classification for many centuries, but due to the changes in the language system the semantic factor, to be exact the contextual semantic factor becomes of primary importance. The concepts are not things, as words are, but rather the functionings of words". So the functioning of a word is interdependent with other words functioning in the sentence pattern or in discourse. The meanings of concepts are properties, objectively given by the structures of reality [11, p. 79-80].

We must keep in mind that the language is a means of communication transferring information about certain situations, topics or opinions. Accordingly, we have to explain the meanings of the utterances we use $[9$, p. 60].

Theoretical background. Proforms can be organized into a paradigm of substition units in written and oral discourse though this paradigm 
is not homogeneous as it differentiates between 1) the "relative substitutes" (structural elements like it (a formal subject), that (a complementizer or a conjunction), etc.) and 2) "direct substitutes" (like personal and demonstrative pronouns, modal and auxiliary verbs, etc.), and semantically bleached words like one or thing, etc. However, neither scholar refers proforms to a definite class of open or closed parts of speech. R. Carter and M. McCarthy admit that all the units substitituting represented by definite and indefinite pronouns, adverds, or auxiliary verbs still retain their original part of speech meaning [2, p. 917]. But they are organized into two lists: List 1: proforms used for coreference and List 2: proforms used for substitution [14, p. 865-866; 10] differentiating them according to the part of speech and point out the difficulty to 'distinguish between ellipsis and substitution [2, p. 248-256].

The English grammar system is abound in proforms among which the pronoun is a true substitution word, see its origin: mid-15c., from pro- and noun; modeled on Middle French pronom, from Latin pronomen, from pro "in place of" + nomen "name, noun" (from PIE root *no-men- "name"), like personal or demonstratives which can, more formally, be substitutes for noun phrases.

Proforms are used in the traditional function of substitution in English grammar: when a word, phrase, or clause in a sentence is replaced by a different word or phrase in order to avoid repeating the previously used word. at the same time they can actualize their periphery components of a filler, discourse particle, deixis. Accordingly we cannot consider them dummies orsemantically bleeched in the discourse structure.

Corpora analysis and discussion. In the1970-es the shift of emphasis from compositionality to integration prompted later studies (e. g. M. A. K. Halliday and R. Hasan, 1976, 1985; T. A. van Dijk and W. Kintsch, 1978, 1983; R.-A. de Beaugrande, 1980) focused on a) the co-functioning of textual components, and b) merging aspects of textual communication into a complex model [6, p. 257], drew the researchers' attention to the proforms, or fillers, or substitution words as units of text cohesion and later pause fillers in discourse, or dummy words.

S. Muller in his "Grammatical theory" stresses that the meaning of the proform is recoverable from the linguistic or extra-linguistic context, though classifies the proforms according to the type of the sentence: pro-negative, pro-interrogative, or a part of speech being substituted: pro-Adjective,
pro-Adverb; pronoun; pro-Verb [9, p. 60]. However, R. A. Jacobs refers the substitute form or proform expressed by the indefinite pronoun it the class of fillers [6, p. 144] which frequency is 1045013 cases registered in the BNC.

It is proved that without using proforms in language, it is almost impossible to produce natural, cohesive texts, either written or spoken M. A. K. Halliday and R. Hasan systematized the major cohesive resources in their book on cohesion [5].

The English grammar system is abound in proforms among which the pronoun is a true substitution word, see its origin: mid-15c., from proand noun; modeled on Middle French pronom, from Latin pronomen, from pro "in place of" + nomen "name, noun" (from PIE root *no-men- "name"), like personal or de tter, genteel" forms of expression (Hornsey, 1793). The use of the wh-forms increased "dramatically" and "almost eclipsed that altogether" [13, p. 43; 8]. But the BNC registers1 108428 cases of that in its text as a conjunction, or a complemetizer, cf: the frequency of wh-units in the BNC of which is 361 506; what is 238 621; who is 197855 ; whose is 19080 .

The Modern English unit one developed from c. 1200, from Old English an (adjective, pronoun, noun) "one", from Proto-Germanic *ainaz (source also of Old Norse einn, Danish een, Old Frisian an, Dutch een, German ein, Gothic ains), from PIE root *oi-no- "one, unique" [3, p. 129, 496].

It is defined as "being but a single unit or individual; being a single person, thing, etc. of the class mentioned"; as a pronoun, "a single person or thing, an individual, somebody; used as a third person substitute for a first person pronoun" (MerriamWebster) [7, p. 331; 4]. The frequency of one is 291900 and its plural form ones is 11359 in the BNC. We shall focus on the units used as substitutes, e.g.:

9. A mask, want to put it on, want to put one on?

10 . New, ludicrously expensive, lightweight saddle, why did all Drew's ponies need one too?

11. So do novelists since his day seek a setting that holds together, and one that gives character a space to breathe and act in.

In illustrations 9-11 one correlates with nouns mask (9), saddle (10), and setting (11) [1, p. 250-251], it helps to avoid repetition and links semantically parts of the sentences, in sentence (11) it is followed by a descriptive attributive clause introducd by the conjunctive that.

12. A royal send off, but then again not many are as special as this one.

13. Well, but I ask you that one. 
In illustrations (12-13) there is a classical combination of one with the demonstrative pronouns this and that depending on the distance of the speaker and the object of his/her choice

14. The Host immediately tries to draw a moral from the tale - an appropriately pragmatic one.

In illustration (14) one as is combined with the adjective pragmatic which together with one are combined wth the adverb an appropriately, i. e. $\mathrm{a}+(($ appropriately $)+($ pragmatic $(+o n e))$. Although when you look up in the dictionary or a grammar book you can find an empty word with the dominant component "substitution", that is the adjuncts of one characterize its coreferents.

15. The best things is to throw pillows away and replace them with new ones which won't contain any allergen.

16. The relationships were not physical ones produced by transmutation, but ideal ones existing in the mind of God.

In illustrations (15-16) the number of ones depends on the number of their corefents (pillows (15)) nouns and they form the Noun Phrase: Adjunct [adjectives] + Head Word [noun] and together with the coreferents theyform a semantic unity.

The Modern English do developed from Middle English $d o$, first person singular of Old English don "make, act, perform, cause; to put, to place", from West Germanic *doanan (source also of Old Saxon duan, Old Frisian $d w a$, Dutch doen, Old High German tuon, German tun), from PIE root *dhe- "to set, put, place".

The do-verb has the high frequency in the BNC: do-267396, did-134 501; does -66470. The verb do is polysemous as a main or full verb may reveal such semantic components in certain contexts: perform, execute, set, arrange, act, behave, etc. though its "meaning is narrowed todown by thenatureofof the object". As an auxiliary verb is a semantically empty ant isemployed asasynatactic constituent of the VerbPhrase in the negative and interrogative sentences [14, p. 120, 136]. R. A. Jacobs calls this verb form an operator of negative, interrogative and tag structures [6, p. 257].

In the text fragments under study the verb $d o$ is used as a proform which traditionally is treated as a dummy with a bleached semantics and can play the role of substitutes [1, p. 252-253] e. g.:

17. I throw in the towel there. I've said it before you did!

18. Tell us that "other European countries" manage their health services better than we $d o$.

19. We will not find words like skive and naff in most dictionaries (or if you do they will be marked "dialectal" or "colloquial").

There are chains of correlation in sentence 17: throw $\rightarrow$ did; in sentence 18: manage $\rightarrow$ do; in sentence 9: will not find do. The coreference reveals the meaning of the do-proform acquired from the main verb-predicate. First, the proforms call for the ellipsis of the sentence structure, second, avoid repetition, third, make the sentence sound natural, fourth, they link parts of the sentence, clauses, and sentences, fifth, they refer the reader/hearer to the meaning of the units they substitute.

Findings and perspective. The proforms under study as well as others registered in in R. Quirk's Lists are the constituents of various word classes in the language system. In language or discourse use they bear the lxical maning of their coreferents. Their functional-semantic meaining is a sum of the lexical meaning of the coreferent and their syntactical function in the definiute context ttat makes the given units elegible for including them into the conceptual system of "substitution".

It is argued that these proforms do not necessarily express a unit at any level of underlying representation. Instead it is suggested, that the theory of Functional Discourse Grammar, with its four different levels of analysis (representing pragmatic, semantic, morphosyntactic, and phonological), is flexibile enough to give a ubiquitous description of English proforms.

\section{References:}

1. English grammar today / R. Carter et al. Cambridge : CUP, 2006. $664 \mathrm{p}$.

2. Carter R., McCarthy M. Cambridge grammar of English. Cambridge : CUP, 2011. 973 p.

3. Celce-Murcia M., Larsen-Freeman D. The grammar book. Boston, MA : Heine Publishers, 1998. 854 p.

4. Reports. The Yugoslav SerboCroatian-English contrastive project / ed. by R. Filipovic. Zagreb : Institute: of linguistics, 1972. $127 \mathrm{p}$.

5. Halliday M. A. K., Hasan R. Cohesion in English. Oxford : OUP, 1976. 374 p.

6. Jacobs R. A. English syntax. A grammar for the English language professionals. Oxford : OUP, 1993. $378 \mathrm{p}$.

7. Kruisinga E. On some uses of one. The Review of English Studies. 1934. Vol. 10. № 39. P. 331-337.

8. Lee D. W. Functional Change in Early English : a dissertation. Whitefish : Literary Licensing, 2012. 140 p.

9. Muller S. Grammatical theory. Berlin : Language Sciences Press, 2016. 839 p. 
10. Mykhaylennko V. V. Correlation of It-deixis and discourse register. Нова філологія. 2011. № 47. C. 94-96.

11. Mykhaylennko V. V. Conceptual analysis: componential analysis. Науковий вісник Чернівеиького національного університету імені Юрія Федьковича. Серія «Германська філологія». 2014. № 720. С. 77-86.

12. Mykhaylennko V. V. It-pronoun: context correlation. Вчені записки Таврійського національного університету імені В. І. Вернадського. Серія «Філологія. Соціальні комунікаиї̈». 2020. Т. 31(70). № 1. Ч. 2. С. $141-145$.

13. Patterns of Change in 18th-century English / T. Nevalainen et al. (eds.). Amsterdam ; Philadelphia : Benjamins, 2018.325 p.

14. A comprehensive grammar of the English language / R. Quirk, S. Greenbaum, G. Leech, J. Svartvik. London : Longman, 2000. 1779 p.

\section{Михайленко В. В. ПРО СТАТУС ПРОФОРМ}

У фокусі статті перебувають специфічні мовні одиниці, що належать до різних частин мови, проте завдяки спільному компоненту, який вони актуалізують у певних контекстах, організовуються в єдину концептуальну підсистему в англомовній картині світу.

Перехід від прескриптивної до дескриптивної граматики ставить дослідника перед вибором методу й інструментів класифікачії зазначених одиниць, а також перед необхідністю перегляду принципів визначення традиційних частин мови, незважаючи на запропоновану чітку класифікацію слів на закриті (прийменник, займенник, сполучник, артиклі чи детермінативи) та відкриті (іменники, прикметники, числівники, дієслова та прислівники) частини мови. Без сумніву, така класифікація є суперечливою щзоо кількості класів і їх номіначій, однак вона може слугувати відправною точкою для функиіонально-семантичного аналізу субститутів у дискурсі, де значення слова в його контексті є основним маркером його класифікаиії. Відповідно, вивчення функиіональної семантики складників тексту/дискурсу, на наше переконання, необхідно починати з концептуального аналізу, який поступово приведе до вивчення морфемної репрезентаџї конщептів. На наму думку, концепти є не речами, як слова, а скоріше «функиіонуваннями» слів. Отже, функиіонування слова залежить від інших слів, що функціонують у межах речення чи дискурсу. Змістом концепту є властивості, що об'єктивно задані структурою дійсності.

Проформи можуть бути організовані в парадигму одиниць зі спільним компонентом «субституиія», актуалізовані в письмовому й усному дискурсі, хоча ия парадигма не є однорідною, оскільки вона розмежсовує, по-перше, «відносні замінники» (структурні елементи), і по-друге, «прямі замінники» (особові та вказівні займенники, модальні й допоміжні дієслова тощь), а також десемантизовані лексеми.

Стверджується, що иі проформи не обов'язково представляють єдиний клас слів на будь-якому рівні. Натомість припускаємо, щзо теорія граматики функиіонального дискурсу із чотирма різними рівнями аналізу (прагматичним, семантичним, морфосинтаксичним і фонологічним) може надати всебічний опис англійських проформ.

Ключові слова: частина мови, субститути, поліфункціональність, речення, дискурс, контекстна семантика, кониепт. 